\title{
PENGGUNAAN METODE DRILL UNTUK MENINGKATKAN KEMAMPUAN SISWA DALAM MENGHAFAL AYAT-AYAT AL-QUR'AN
}

\author{
SUHARTA
}

SMA Negeri 1 Cikande, Serang

Suhartaarsadi22240@gmail.com

\begin{abstract}
ABSTRAK
Menghafalkan ayat-ayat al-Qur'an adalah kompetensi yang sulit untuk dicapai para siswa di sekolah umum, metode pembelajaran yang tidak menarik menjadi pemicu kesulitan siswa dalam menguasai kompetensi ini. Penelitian ini fokus pada kajian penerapan model drill dalam upaya meningkatkan kemampuan hafalan siswa terhadap ayat-ayat pilihan. Penelitian Tindakan Kelas ini dilakukan dalam dua siklus, dan tampak kenaikan skor variabel yang diteliti cukup signifikan pada siklus kedua. Skor rata-rata aktivitas siswa yang relevan dengan pembelajaran mengalami peningkatan dari siklus pertama sebesar 80,00 \% menjadi 90,77\%, mengalami kenaikan sebesar $10,77 \%$. Sedangkan skor rata-rata aktivitas siswa yang kurang relevan dengan pembelajaran mengalami penurunan sebesar $9,40 \%$, pada siklus pertama rata-rata skor $17,09 \%$, sedangkan pada siklus kedua sebesar 7,69\%. Kemampuan siswa menghafal surah an-Nisa ayat 59 pada siklus pertama sebesar 74,03 dan pada siklus kedua sebesar 83,36, tergolong baik, demikian juga ketuntasan belajar pada siklus pertama 58,97\% dan pada siklus kedua menjadi $87,18 \%$. Berdasarkan temuan hasil penelitian ini dapat disimpulkan bahwa model drill dapat meningkatkan kemampuansiswa dalam menghafal surah an-Nisa ayat 59 pada pelajaran Pendidikan Agama Islam pada siswa kelas XI IPA 1 SMA Negeri 1 Cikande Serang.
\end{abstract}

Kata Kunci : metode drill, menghafal al-Qur'an, hafalan siswa.

\section{ABSTRACT}

Memorizing the verses of the Qur'an is a difficult competency for students to achieve in public schools, unattractive learning methods trigger students' difficulties in mastering this competency. This research focuses on the study of the application of the drill model in an effort to improve students' memorization skills of selected verses. This Classroom Action Research was conducted in two cycles, and it appears that the increase in the scores of the variables studied was quite significant in the second cycle. The average score of student activities that are relevant to learning has increased from the first cycle of $80.00 \%$ to $90.77 \%$, an increase of $10.77 \%$. While the average score of student activities that are less relevant to learning has decreased by $9.40 \%$, in the first cycle the average score is $17.09 \%$, while in the second cycle it is $7.69 \%$. The ability of students to memorize surah an-Nisa verse 59 in the first cycle was 74.03 and in the second cycle was 83.36, classified as good, as well as mastery learning in the first cycle was $58.97 \%$ and in the second cycle was $87.18 \%$. Based on the findings of this study, it can be concluded that the drill model can improve students' ability to memorize Surah an-Nisa verse 59 in Islamic Religious Education lessons for students in class XI IPA 1 SMA Negeri 1 Cikande Serang.

Keywords: drill method, memorizing the Qur'an, memorizing students.

\section{PENDAHULUAN}

A-Qur'an adalah komponen utama yang ada dalam kurikulum Pendidikan Agama Islam. Dalam kompetensi komponen al-Qur'an, siswa dituntut agar dapat membaca, memahami dan menghafalkan ayat-ayat pilihan. Menghafal ayat al-Qur'an menjadi sangat penting, karena hafalan al-Qur'an tersebut selain bisa mengasah kemampuan otak untuk menghafal juga bisa digunakan dalam pelaksanaan shalat fardhu maupun shalat sunnat.

Pada tiap semester dan tiap kelas selalu ada tuntutan kurikulum Pendidikan Agama Islam agar siswa mampu membaca dan menghafal ayat-ayat ayat al-Qur'an yang berkaitan dengan materi yang akan dipelajari. Namun patut disayangkan, pengalaman mengajar tahun- 


\section{EDUCATIONAL : Jurnal Inovasi Pendidikan dan Pengajaran Vol. 1 No. 4 November 2021 e-ISSN : 2775-2593 | p-ISSN : 2775-2585}

tahun sebelumnya, siswa masih banyak yang kesulitaan menghafal ayat-ayat al-Qur'an tersebut dalam rentang waktu yang disediakan. Bahkan ketika diberikan waktu tambahan untuk menghafal ayat al-Qur'an, siswa masih belum bisa menghafal dengan baik. Yang lebih menyedihkan ada beberapa siswa yang belum bisa membaca al-Qur'an.

Tidak semua siswa SMA punya kemauan untuk mengaji di rumah, pesantren, majlis ta'lim atau mengikuti pendidikan agama di Madrasah Diniyah. Kesibukan orang tua yang keduanya harus bekerja mencari nafkah menyebabkan terbengkalainya pendidikan al-Qur'an bagi anak-anak mereka. Kurangnya penanaman akan arti pentingnya memahami dan mengamalkan al-Qur'an menjadi faktor utama timbulnya rasa malas dan rendahnya minat siswa untuk berinteraksi dengan al-Qur'an baik sekedar membaca lebih lebih menghafalkannya.

Kurangnya minat itu terlihat dari tidak ada gairah dan antusias apabila mereka diminta untuk menghafal ayat al-Qur'an, sikap acuh tak acuh, menghafal asal-asalan, sambil bercanda pada temannya, bahkan ada yang memilih untuk mengobrol dengan teman-teman yang lain. Bisa di tebak, hasil hafalannya terutama untuk menghafal ayat-ayat al-Qur'an dengan artinya akan lebih banyak siswa yang belum hafal dibandingkan dengan yang hafal, apalagi jika tuntutannya adalah hafal dengan lancar dan sesuai dengan makharijul huruf, tentu harapan akan jauh panggang dari api.

Dari uraian di atas, penulis dapat mengidentifikasi beberapa persoalan yang menjadi agenda untuk dapat dipecahkan melalui penelitian ini, yaitu: 1) rendahnya motivasi siswa dalam menghafal ayat-ayat pilihan; 2) rendahnya kemampuan siswa dalam menghafalkan ayat pilihan; 3) rendahnya kemampuan siswa dalam mempertahankan hafalan ayat al-Qur'an. Tiga temuan tersebut kemudian penulis diskusikan dengan sesama teman sejawat untuk mendapatkan masukan dan pandangan konstruktif. Hasil diskusi dan reiew terhadap beberapa literatur yang mengkaji permasalahan yang sama, diantaranya (Hasanah, 2015), maka penulis dapat mengidentifikasi beberapa faktor penyebab, diantaranya: 1) metode pembelajaran yang digunakan kurang menarik minta siswa; 2) Suasana pembelajaran mampu meningkatkan prestasi hafalan siswa; 3) teknik hafalan yang selama ini digunakan belum memberikan efek signifikan terhadap peningkatan prestasi hafalan siswa. Relevan dengan temuan tersebut, maka penulis menawarkan beberapa alternatif solusi yang menurut penulis dapat dijadikan solusi untuk mengatasi permasalahan tersebut, diantaranya: 1) penggunaan metode baru yang dapat menumbuhkan minat belajar siswa; 2) pengkondisian suasana kelas agar dapat meningkatkan kemampuan hafalan, dan 3) penggunaan teknik atau alat yang dapat memudahkan menghafal ayat-ayat al-Qur'an.

Ketiga permasalahan tesebut dapat diselesaikan dengan solusi pertama, yaitu penggunaan metode pembelajaran yang epektif sehingga dapat mengatasi ketiga permasalahan di atas. Penggunaan metode pembelajaran yang epektif akan meningkatkan motivasi siswa (Musyaffa, 2015) dalam menghafalkan ayat al-Qur'an, dengan motivasi belajar yang tinggi maka prestasi hafalan juga dengan sendirinya akan meningkat.

Relevan dengan itu, hasil penelitian para ahli pendidikan menyebutkan bahwa cara kerja otak itu mengikuti sistem limbik, ia akan bekerja jika tebuka, dan dia akan terbuka kalau situasinya menyenangkan, maka belajar akan lebih berhasil bila situasinya menyenangkan (Purwati, 2016; Sagala, 2009). Kegiatan belajar mengajar akan lebih epektif jika siswa memiliki minat yang besar terhadap kegiatan belajar itu (Sutikno, 2009: 16). Pendapat lain menyebutkan bahwa menghafal akan lebih epektif dengan melibatkan otak kanan. Karena salah satu sifat kelebihan yang dimiliki otak kanan adalah dapat menyimpan memori hafalan dalam waktu yang relatif lebih penjang (Long Term Memory). Dengan menghafal, kita bisa langsung memahami, menulis, dan menghafal dengan mudah dan cepat. Otak kanan memiliki proses kerja yang unik, otak kanan bekerja melalui hafalan yang berkesan, rasa cinta yang tinggi dan ikatan memori yang terbangun dari rasa yang ada dalam hati (Bobby, 2012).

Salah satu metode yang dapat memberikan kemudahan kepada siswa dalam menghafal ayat-ayat al-Qur'an adalah metode latihan atau drill. Metode drill merupakan metode pembelajaran yang digunakan untuk memperoleh ketangkasan atau keterampilan dalam 


\section{EDUCATIONAL : Jurnal Inovasi Pendidikan dan Pengajaran Vol. 1 No. 4 November 2021 e-ISSN : 2775-2593 | p-ISSN : 2775-2585}

menghafal surah-surah pendek pilihan yang diulang-ulang sampai siswa hafal dengan bacaan tanpa melihat teks (Falila, 2018). Dalam pembelajaran agama Islam, materi bisa diajarkan dengan metode ini karena bersifat pembiasaan, ketika pembiasaan ini sudah berjalan maka siswa akan mampu membaca teks-teks atau ayat-ayat al-Qur'an tanpa harus melihat kepada teks tersebut.

Berangkat dari rendahnya kemampuan siswa dalam menghafal ayat-ayat Al-Qur'an khususnya surah-surah pendek, dan keyakinan penulis akan epektifitas pengunaan metode $d r i l l$ dalam menghafal ayat-ayat ayat-ayat al-Qur'an (setidaknya didasarkan pada hasil penelitian Falila, 2018), penulis berencana menerapkan model drill dalam pembelajaran di kelas ketika membahasa materi tentang hafalan al-Qur'an surah an-Nisa ayat 59. Untuk memastikan proses dan keberhasilannya, penulis mencoba mengemasnya dalam kegiatan Penelitian Tindakan Kelas dengan judul : Upaya Peningkatan Kemampuan Menghafal Al-Qur'an Surah an-Nisa Ayat 59 dengan Model Drill pada Siswa Kelas XI IPA 1 di SMA Negeri 1 Cikande.

\section{METODE PENELITIAN}

Penelitian ini dilaksanakan selama 2 (dua) bulan, dimulai pada Juli 2019 sampai dengan bulan Agustus 2019 dilakukan di SMAN 1 Cikande Kabupaten Serang pada siswa kelas XI IPA 1 Semester I Tahun Pelajaran 2019/2020, dengan jumlah siswa 40 orang, yang terdiri dari 12 orang laki-laki dan 28 orang perempuan. Penelitian dilaksanakan pada saat mata pelajaran Pendidikan Agama Islam berlangsung dengan materi tentang hafalan surah an-Nisa ayat 59.

Penelitian ini merupakan pengembangan dari metode dan strategi pembelajaran di kelas. Jenis penelitian ini tergolong pada Penelitian Tindakan Kelas (Class Action Research) yaitu suatu penelitian tindakan yang dilakukan di kelas ketika kami melakukan proses pembelajaran, tujuannya adalah untuk memperbaiki atau meningkatkan kemampuan siswa dalam hafalan surah pilihan, hal ini sesuai dengan apa yang dikatakan oleh arikunto bahwa PTK bertujuan untuk memecahkan permasalan pembelajaran dalam kelas (Arikunto, Supardi, dan Suhardjono, 2021). Alat pengumpul data yang dipakai dalam penelitian ini antara lain: catatan guru, catatan siswa, wawancara, angket dan berbagai dokumen yang terkait dengan siswa. Prosedur penelitian terdiri dari 4 tahap, yakni perencanaan, melakukan tindakan, observasi, dan evaluasi. Refleksi dalam tahap siklus dan akan berulang kembali pada siklus-siklus berikutnya.

Aspek atau variabel yang diamati dalam setiap siklusnya adalah kegiatan atau aktifitas siswa yang relevan dan aktifitas siswa yang tidak relevan saat kegiatan pembelaaran mata pelajaran PAI dengan pelaksanaan drilling al-Qur'an Surah al-Nisa: 59. Penggunaan metode drill merupakan pilihan yang rasional karena metode ini epektif penggunaanya dalam pembelajaran PAI khusunya untuk materi hafalan ayat-ayat al-Qur'an. Dengan penggunaan metode ini siswa lebih aktif dan selalu berinisiatif untuk selalu berlatih menguasai materi yang diberikan (Munawaroh, 2019).

Penggunaan metode drill bertujuan untuk melihat perubahan tingkah laku siswa, untuk mengetahui tingkat kemajuan belajarnya yang akan berpengaruh terhadap hasil belajar dengan alat pengumpul data yang sudah disebutkan di atas. Data yang diambil adalah data kuantitatif dari hasil tes serta data kualitatif yang menggambarkan aktivitas siswa yang relevan dengan pembelajaran. Instrumen yang dipakai berbentuk: soal tes lisan, observasi, catatan lapangan. Data yang terkumpul dianalisis untuk mengukur indikator keberhasilan yang sudah dirumuskan.

\section{HASIL DAN PEMBAHASAN}

Pada bagian ini akan ditampilkan hasil penelitian dan pembahasannya, hasil penelitian berupa data-data hasil pengamatan dan hasil tes akan disuguhkan lebih dahulu, lalu dianalisis, setelah itu baru kemudian diinterpretasikan dan dibahas untuk menemukan makna di balik datadata yang telah didapatkan dari pengamatan dan tes. 
Hasil

Penelitian ini dilakukan dalam dua siklus. Pada setiap siklus, data yang diambil adalah aktivitas siswa selama proses pembelajaran dalam satu siklus dan nilai evaluasi lisan yang diambil pada akhir setiap siklus. berikut ini:

Hasil observasi aktivitas siswa dari siklus ke siklus dapat dilihat pada Tabel-tabel

Tabel 3. Data aktivitas siswa yang relevan dengan pembelajaran.

\begin{tabular}{clccc}
\hline \multirow{2}{*}{ No. } & \multicolumn{1}{c}{ Indikator } & \multicolumn{3}{c}{ Prosentase } \\
\cline { 3 - 5 } & & Siklus I & Siklus II & Selisih \\
\hline $\mathbf{1}$ & $\begin{array}{l}\text { Siswa memperhatikan guru ketika } \\
\text { guru membaca surah an-Nisa ayat 59 }\end{array}$ & 84.62 & 89.74 & 5.13 \\
$\mathbf{2}$ & $\begin{array}{l}\text { Siswa membaca surah an-Nisa ayat 59 } \\
\text { secara klasikal }\end{array}$ & 71.79 & 87.18 & 15.38 \\
$\mathbf{3}$ & $\begin{array}{l}\text { Siswa membaca surah an-Nisa ayat 59 } \\
\text { per dua baris }\end{array}$ & 76.92 & 89.74 & 12.82 \\
$\mathbf{4}$ & $\begin{array}{l}\text { Siswa membaca surah an-Nisa ayat 59 } \\
\text { secara per baris }\end{array}$ & 76.92 & 89.74 & 12.82 \\
$\mathbf{5}$ & $\begin{array}{l}\text { Siswa mengulang-ulang kembali } \\
\text { bacaan surah an-Nisa ayat 59 }\end{array}$ & 89.74 & 97.44 & 7.69 \\
\hline & $\quad$ Rata-rata & 80.00 & 90.77 & 10.77
\end{tabular}

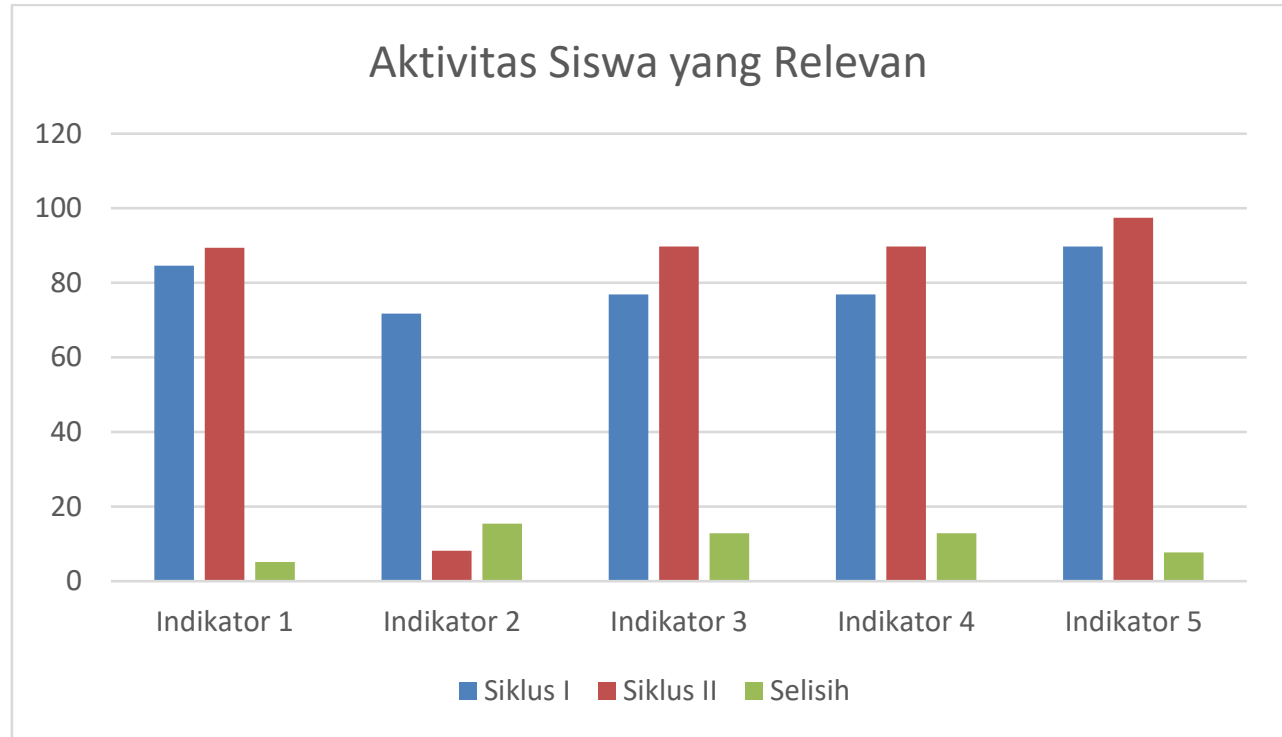

Gambar 1. Aktivitas Siswa yang Relevan

Berdasarkan Tabel 3 di atas, tampak bahwa aktivitas siswa yang relevan dengan kegiatan pembelajaran pada siklus II mengalami peningkatan dibandingkan dengan siklus I yaitu rata-rata sebesar $10,77 \%$.

Selanjutnya data aktivitas siswa yang kurang relevan dengan pembelajaran terlihat pada Tabel 4.

Tabel 4. Data Aktivitas Siswa yang kurang relevan dengan pembelajaran

\begin{tabular}{ccccl}
\multirow{2}{*}{ No. } & \multicolumn{2}{|}{ Indikator } & \multicolumn{3}{c}{ Ketercapaian } \\
\cline { 3 - 5 } & & Siklus I & Siklus II & Selisih \\
\hline 1 & Tidak memperhatikan bacaan guru & 15.38 & 10.26 & 5.13 \\
2 & Tidak ikut serta membaca & 25.64 & 10.26 & 15.38
\end{tabular}




\begin{tabular}{ccccc}
3 & Tidak mengulang bacaan & 10.26 & 2.56 & 7.69 \\
\hline Rata - rata & 17.09 & 7.69 & 9.40 \\
\hline
\end{tabular}

\section{Aktivitas tidak Relevan}

30

25

20

15

10

0

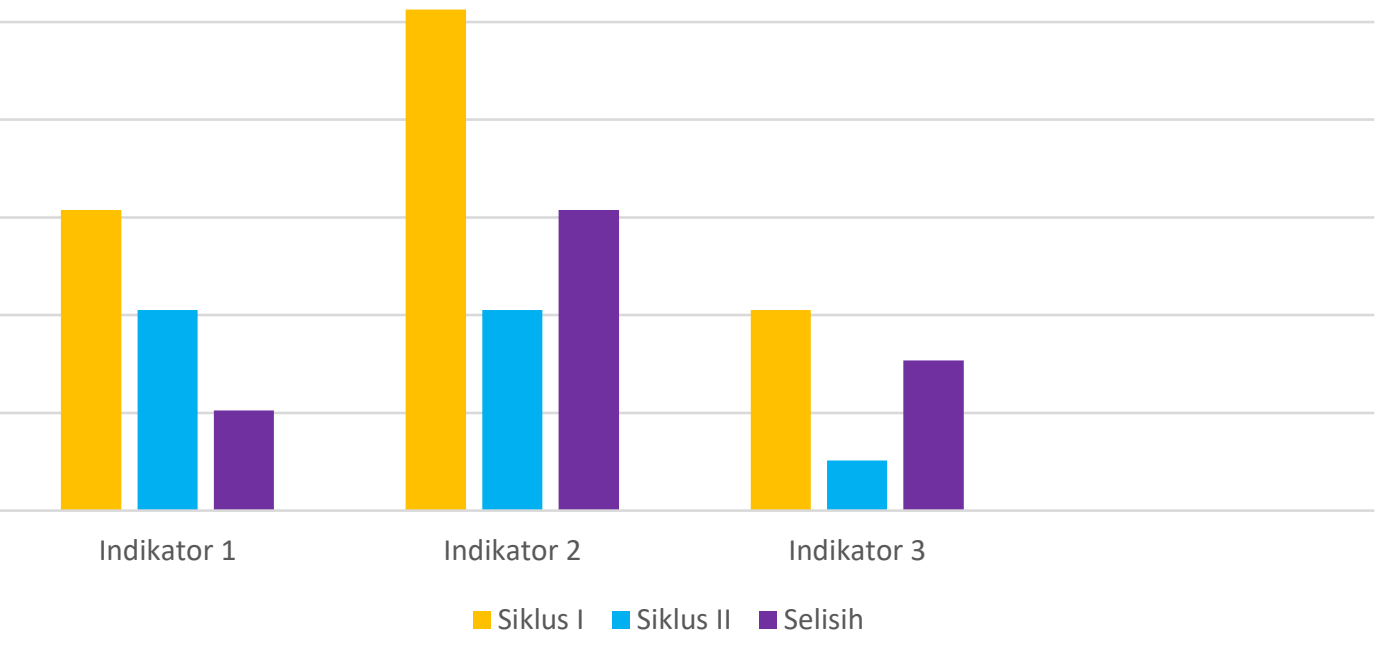

\section{Gambar 2. Aktivitas tidak Relevan}

Berdasarkan Tabel 4 di atas terlihat bahwa aktivitas siswa yang kurang relevan dengan kegiatan pembelajaran pada siklus II mengalami penurunan dibandingkan dengan siklus I yaitu rata-rata sebesar $9,40 \%$.

Data pemahaman siswa tentang materi hafalan surah an-Nisa ayat 59 dan ketuntasan belajar dari siklus ke siklus dapat dilihat pada Tabel 5 sebagai berikut.

Tabel 5. Nilai hafalan siswa dan ketuntasan belajar siswa.

\begin{tabular}{clccc}
\hline \multirow{2}{*}{ No. } & \multirow{2}{*}{ Aspek yang diamati } & \multicolumn{3}{c}{ Ketercapaian } \\
\cline { 3 - 4 } & Nilai rata-rata hafalan & Siklus I & Siklus II & Selisih \\
\hline 1 & Siswa yang telah tuntas & $58.07 \%$ & 83.36 & 9.33 \\
3 & Siswa yang belum tuntas & $41.03 \%$ & $12.82 \%$ & $-28.21 \%$ \\
\hline
\end{tabular}
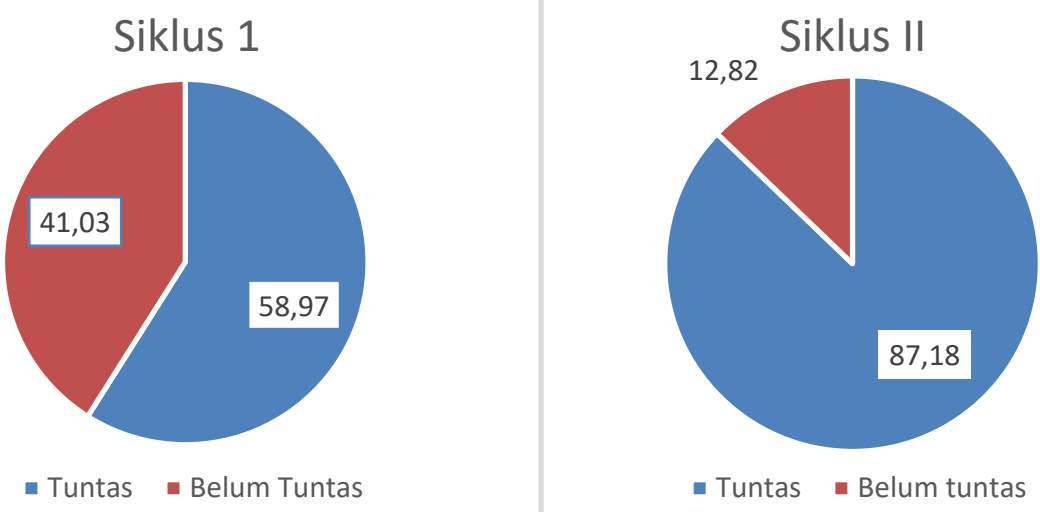

Gambar 3. Prosentasi Ketuntasan Nilai Hafalan Siswa 


\section{EDUCATIONAL : Jurnal Inovasi Pendidikan dan Pengajaran Vol. 1 No. 4 November 2021 e-ISSN : 2775-2593 | p-ISSN : 2775-2585}

Berdasarkan Tabel 5 di atas, nilai rata-rata kemampuan siswa menghafal surah an-Nisa ayat 59 mengalami peningkatan dari siklus I ke siklus II sebesar 9.33, begitu juga prosentase siswa yang mencapai ketuntasan belajar meningkat dari siklus I ke siklus II sebesar 28,21\%

\section{Pembahasan}

Siklus pertama dilaksanakan dalam 1 kali pertemuan. Siswa dibagi menjadi 4 baris tempat duduk dengan tiap baris berpasangan dan tiap baris terdiri dari 5 pasang atau 10 orang. Setiap siswa membuka buku paket PAI pada halaman yang tercantum surah an-Nisa ayat 59 atau membuka Al-Quran pada halaman yang tertera di halaman itu surah an-Nisa ayat 59.

Hasil pengamatan guru menunjukan pada kegiatan drill siklus pertama tentang hafalan surah an-Nisa ayat 59, terlihat para siswa sangat antusias dalam memperhatikan bacaan, mengikuti instruksi guru untuk membaca Al-Qur'an surah an-Nisa ayat 59 baik secara klasikal, per dua baris tempata duduk maupun per baris tempat duduk.

Berdasarkan Tabel 3 di atas terlihat keaktifan siswa memperhatikan guru ketika guru membaca surah an-Nisa ayat 59 pada siklus I sebesar $84.62 \%$ sedangkan pada siklus II sebesar $89.74 \%$, mengalami kenaikan $5.13 \%$. Begitupun dalam indikator Siswa membaca surah anNisa ayat 59 secara klasikal pada siklus I sebesar $71.79 \%$ dan pada siklus II $87.18 \%$ mengalami kenaikan $15.38 \%$. Pada indikator Keterlibatan siswa dalam membaca surah an-Nisa ayat 59 per dua baris pada siklus I $76.92 \%$ dan pada siklus II $89.74 \%$ mengalami kenaikan sebesar $12.82 \%$. Pada indikator siswa membaca surah an-Nisa ayat 59 per baris, pada siklus I $76.92 \%$ dan pada siklus II $89.74 \%$ mengalami kenaikan sebesar $12.82 \%$. Dalam indikator interaksi siswa mengulang-ulang kembali bacaan surah an-Nisa ayat 59, pada siklus I $89.74 \%$ sedangkan pada siklus II $97.44 \%$ mengalami kenaikan sebesar $7.69 \%$.

Sejalan dengan itu, sebagaimana ditunjukan pada Tabel 4, aktivitas siswa yang tidak relevan mengalami penurunan signifikan, pada indikator tidak memperhatikan bacaan guru pada siklus I 15,38 \% mengalami penurunan 5.13\%, sehingga pada siklus kedua hanya sebesar $10,26 \%$. Adapun indikator siswa tidak ikut serta membaca sebesar $25.64 \%$ pada siklus I dan sebesar $10.26 \%$ pada siklus II, sehingga terjadi penurunan $15.38 \%$. sementara indikator siswa yang tidak mau mengulangi bacaan individual terjadi penurunan sebesar 7,69\% dari semula $10.26 \%$ pada siklus I menjadi $2.56 \%$ pada siklus II. Sehingga jika di rata-rata terjadi penurunan $9.40 \%$ dari rata-rata $17.09 \%$ pada siklus I menjadi $7.69 \%$ pada siklus II.

Sementara itu berdasar Tabel 5, tampak bahwa nilai rata-rata kemampuan siswa dalam menghafalkan surah an-Nisa ayat 59 pada silklus I sebesar 74.03 dan pada siklus II sebesar 83.36 mengalami kenaikan sebesar 9.33. Siswa yang telah tuntas pada siklus I sebesar $58.97 \%$ dan pada siklus II sebesar 87,18\% mengalami kenaikan sebesar 28,21\%. Sehingga siswa yang belum tuntas yang pada siklus I sebesar $41,03 \%$ menjadi $12,82 \%$ pada siklus II, artinya mengalami penurunan sebesar $28.21 \%$.

Melalui metode drill ini terlihat bahwa keterlibatan siswa dalam aktivitas pembelajaran sangat tinggi, proses pembelajaran juga tidak membuat mereka mengantuk karena seluruh anggota tubuh mereka terlibat dalam pembelajaran, hasil tes hafalan pun terlihat meningkat secara signifikan.

Dari penggunaan model drill ini terdapat temuan lain, diantaranya ada sejumlah siswa yang belum dapat membaca Al-Qur'an, ada yang dapat membaca namun masih belum lancar dan ada yang sudah lancar. Diantara yang sudah lancar bahkan ada siswa yang telah dapat mendemonstrasikan hafalan dengan menggunakan irama yang merdu.

Berdasarkan hasil Penelitian Tindakan Kelas di atas prosentasi ketercapaian pada siklus pertama mengalami peningkatan yang signifikan pada siklus kedua, maka dapat disimpulkan bahwa temuan pada penelitian menjawab hipotesis bahwa melalui model drill dapat meningkatkan hasil belajar siswa berupa kemampuan menghafal surah an-Nisa ayat 59 dalam mata pelajaran Pendidikan Agama Islam pada siswa kelas XI IPA 1 di SMAN 1 Cikande.

Temuan ini selaras dengan penelitian Sapriadi yang menggunakan metode drill dalam upayanya meningkatkan kemampuan menghafal surah-surah pendek. Dalam penelitiannya 
tersebut Sapriadi menemukan peningkatan kemampuan hafalan-hafalan surah pendek siswa yang ditelitinya secara bertahap dari siklus I, II dan III (Sapriadi, 2013). Demikian juga penelitian Falila yang dalam penelitannya terhadap siswa dan guru di Kabupaten Sorong menemukan adanya peningkatan signifikan dalam kemampuan siswanya menghafal al-Qur'an sehingg dia merekomendasikan penggunaan metode drill ini dalam kegiatan pendidikan agama Islam (Falila, 2018).

\section{KESIMPULAN}

Berdasarkan hasil penelitian, terdapat beberapa temuan dalam penelitian tindakan kelas ini, yaitu skor rata-rata aktivitas siswa yang relevan dengan pembelajaran mengalami peningkatan dari siklus pertama sampai siklus kedua. Pada siklus pertama sebesar $80,00 \%$ menjadi $90,77 \%$ mengalami kenaikan sebesar $10,77 \%$. Skor rata-rata aktivitas siswa yang kurang relevan dengan pembelajaran mengalami penurunan dari siklus pertama sampai siklus kedua. Pada siklus pertama rata-rata skor aktivitas siswa yang tidak relevan sebesar 17,09\%, sedangkan pada siklus kedua sebesar 7,69\% mengalami penurunan sebesar 9,40\%.

Skor rata-rata kemampuan siswa menghafal surah an-Nisa ayat 59 pada siklus pertama sebesar 74,03 dan pada siklus kedua pada 83,36, tergolong baik, demikian juga tentang penuntasan belajar pada siklus pertama $58,97 \%$ dan pada siklus kedua menjadi $87,18 \%$. Berdasarkan temuan hasil penelitian ini dapat disimpulkan bahwa model drill dapat meningkatkan kemampuan siswa dalam menghafal surah an-Nisa ayat 59 pada pelajaran Pendidikan Agama Islam pada siswa kelas XI IPA 1 SMA Negeri 1 Cikande Serang.

\section{DAFTAR PUSTAKA}

Arikunto, Suharsimi., Supardi., dan Suhardjono. (2021). Penelitian Tindakan Kelas. Jakarta: Bumi Aksara.

Bobby, Herwibowo. (2012). Kauny Quantum Memory; Menghafal Al-Qur'an Semudah Tesenyum. Jakaarta: Zaytuna.

Falila, Kalsum. (2018). Penerapan Metode Drill untuk Meningkatkan Kemampuan Menghafal Al-Qur'an Surah Al-Fil pada Mata Pelajaran Pendidikan Agama Islam Kelas IV SD Inpres 17 Kabupaten Sorong. STAIN Sorong.

https://repository.iainsorong.ac.id/items/show/13.

Munawaroh, Sri. (2019). Penerapan Metode Drill dalam Peningkatan Hasil Belajar. Purwokerto: IAIN Purwokerto.

Musyaffa, Akbar. 2015. Peningkatan Prestasi Belajar Siswa Melalui Metode Pengajaran Variatif Pada Mata Pelajaran IPS Di SMP Negeri 1 Losari Kabupaten Brebes. Cirebon: IAIN Syekh Nurjati

http://webcache.googleusercontent.com/search?q=cache:lhnI4n6G3WEJ:repository.syekhnurj ati.ac.id/2077/1/AKBAR\%2520MUSYAFFA.pdf+\&cd=7\&hl=id\&ct=clnk\&gl=id.

Purwati, Eni. (2016). Optimalisasi Pendidikan Islam Melalui Pembelajaran Berbasis Cara Kerja Otak." ISLAMICA: Jurnal Studi Keislaman $11 \quad$ (1): 86-112. http://islamica.uinsby.ac.id/index.php/islamica/article/view/309.

Sagala, Saiful. (2009). Konsep dan Makna Pembelajaran. Bandung: Alfabeta.

Sapriadi. (2013). Penerapan Metode Latihan (drill) untuk Meningkatkan Kemampuan Siswa Membaca Sejumlah Surah-Surah Pendek Pilihan pada Mata Pelajaran Agama Islam Siswa Kelas IV Sekolah Dasar Negeri 56 Kelurahan Balai Makam Duri. Riau: Universitas Islam Negeri Sultan Syarif Kasim Riau.

Sutikno, M. Sobry. (2009). Belajar dan Pembelajaran. Bandung: Prospect. 